\title{
Climate Change AND THE RESOURCE MANAGEMENT ACT 1991: A CRITIQUE OF WEST COAST ENT INC $\checkmark$ BULLER COAL LTD
}

\author{
Nathan Jon Ross*
}

\begin{abstract}
In West Coast ENT v Buller Coal, the majority of the Supreme Court concluded that the effect of the Resource Management (Energy and Climate Change) Amendment Act 2004 was to remove all considerations of the effects of greenhouse gas emissions on climate change. The plain words of the amendment provisions only removed such considerations in relation to air discharge and coastal permits. However, a literal interpretation of those provisions permitted "back door" regulation via ancillary consents of other classes, such as land use consents. The Court concluded, therefore, that to avoid that outcome, the purpose of the Amendment Act must have been to remove all considerations of emissions and the drafters must have only envisaged that those considerations would be relative to air discharge permits. This article re-examines the effect of the 2004 Amendment Act in light of its purpose and legislative history, and in light of the Principal Act's purpose and scheme. It concludes that Parliament was seeking only to remove consideration of emissions that were anticipated to be regulated nationally. It identifies a nuanced method of using the scheme of the Act to allow that purpose to function whilst avoiding the risk of "back door" regulation. This article also critiques the extent to which the majority's interpretation expands and alters the meaning of the plain words of the Amendment Act's provisions.
\end{abstract}

\section{INTRODUCTION}

In West Coast ENT Inc $v$ Buller Coal Ltd, the Supreme Court dismissed an appeal by conservation groups against a declaratory judgment made in favour of coal mining companies under

* LLB (VUW), BEnvSc (Newcastle), Barrister and Solicitor of the High Court of New Zealand. The author would like to thank Sally Gepp for her invaluable input into the development of this article. The author would also like to thank Sir Geoffrey Palmer KCMG AC QC, Hon Justice Matthew SR Palmer, Dean Knight and Associate Professor Alberto Costi for commenting on drafts. 
the Resource Management Act 1991 (RMA) (Principal Act). ${ }^{1}$ That declaration was to the effect that decision makers, when considering land use consents to mine coal, cannot have regard to subsequent discharges of greenhouse gases when that coal is later combusted. ${ }^{2}$

In upholding the declaration made first by the Environment Court $^{3}$ and upheld also by the High Court, ${ }^{4}$ the majority of McGrath, William Young and Glazebrook JJ concluded: ${ }^{5}$

[I]t is not open to territorial authorities and regional councils to regulate activities by reference to the effect on climate change of discharges of greenhouse gases which result indirectly from such activities.

This result was an interpretation of the Resource Management (Energy and Climate Change) Amendment Act 2004 (Amendment Act), which was being tested primarily against the effect of s 104(1)(a) of the Principal Act. The Amendment Act removed regional councils' powers to consider the effects of greenhouse emissions when dealing with two of the five types of consents under the RMA: discharge and coastal permits. ${ }^{6}$ In contrast, s 104(1)(a) directs consent authorities to have regard to "any actual or potential effects on the environment of allowing the activity" when considering all types of resource consents.

The majority concluded, based on the purpose provision of the Amendment Act and the scheme of the RMA, that the Amendment Act's effect was not limited to air discharge consents. Consequently: ${ }^{7}$

[I]n s 104(1)(a), the words "actual or potential effects on the environment" ... do not extend to the impact on climate change of the discharge into air of greenhouse gases that result indirectly from [an] activity.

Such limitation seems to us to be justified as a matter of necessary implication, essentially on the basis that, when the amended RMA is looked at as a whole, the limitation is so obvious that it goes without saying.

1 West Coast ENT Inc v Buller Coal Ltd [2013] NZSC 87, [2014] 1 NZLR 32; and Resource Management Act 1991, ss 310-311.

2 Buller Coal Ltd v West Coast Ent Inc [2012] NZEnvC 80, [2012] NZRMA 401 at [4].

3 Buller Coal Ltd $v$ West Coast Ent, above n 2.

4 Royal Forest and Bird Protection Society of New Zealand Inc v Buller Coal Ltd [2012] NZHC 2156, (2012) 17 ELRNZ 220.

$5 \quad$ West Coast ENT Inc v Buller Coal Ltd, above n 1, at [175].

6 Section 87.

7 West Coast ENT Inc v Buller Coal Ltd, above n 1, at [172]-[173]. 
This conclusion means that discharges of greenhouse gases can never be considered for any activity, except for the benefits to be derived from renewable energy development, which is an exception specifically provided for in the Amendment Act.

In contrast, Elias $\mathrm{CJ}$ in dissent ${ }^{8}$ concluded that the consideration of greenhouse emissions was removed only in relation to air discharge permits. That conclusion was reached on the basis of an alternative purposive approach. Under this interpretation, consent authorities remained authorised to consider effects on climate change of all other planning and consent processes, including the effects of the end use of activities. ${ }^{9}$

It is contended here that Elias CJ's approach should have been preferred, but with the addition of a limiting qualification: that the consideration of greenhouse gas emissions should have also been removed in relation to activities that are ancillary to those activities requiring air discharge consents. This conclusion is reached after four primary steps of reasoning. First, in Part IV, a purposive interpretation is reassessed. This involves reconciling the conflicting purposes of the Principal and Amendment Acts, which in turn involves examining the legislative history of the Amendment Act relative to the state of affairs that existed at the time. It also entails exploring the relationship between the Amendment Act and the Climate Change Response Act 2002 (CCRA). Secondly, in Part V, the alternative conclusion is supported by demonstrating how the scheme of the RMA could operate effectively with this approach. Thirdly, in Part VI, a critique of the gloss applied by the majority to the Amendment Act demonstrates weaknesses in its approach, thereby supporting the need for an alternatively reasoned approach. Finally, in Part VII, this analysis shows that it would have been appropriate to apply an international law lens to interpreting the Amendment Act.

\section{WHY THIS DECISION MATTERS: THE SCIENTIFIC CONTEXT}

Before analysing the judgment, it is important to briefly reiterate the imperative for mitigating greenhouse gas emissions. The science of climate change does not need repeating, but it is worth noting that the "greenhouse effect" was groundbreaking only when it was first scientifically described in 1824 and that "climate change" was groundbreaking only when it was first scientifically described in $1895 .{ }^{10}$ Any denial of anthropogenic climate change in the 21 st century is fallacious.

8 Chambers $\mathbf{J}$ sat on the hearing but died before delivery of the judgment. The Court delivered its judgment as a bench of four under s 30(1) of the Supreme Court Act 2003.

9 At [4], [69] and [85].

10 See David Wogan "Why we know about the greenhouse effect" (16 May 2013) Scientific American <www.scientificamerican.com>. 
Contemporary climate science is predominantly about tracking changes, and improving and updating forecasts for risk management. ${ }^{11}$ It tells us that the safe level of carbon dioxide $\left(\mathrm{CO}_{2}\right)^{12}$ in the atmosphere is 350 parts per million ${ }^{13}$ but the current level is around 400 parts per million; ${ }^{14}$ that we are very close to being too late to avoid extreme impacts that will be catastrophic for human societies; ${ }^{15}$ and that net emissions of greenhouse gases will need to be zero some time between 2080 and $2100 ;{ }^{16}$ but that the rate of global and domestic emissions is still increasing, not decreasing. ${ }^{17}$

The "global carbon budget" is the maximum amount of $\mathrm{CO}_{2}$ that can be emitted into the atmosphere to have an 80 per cent probability of staying within the internationally agreed maximum temperature increase of two degrees Celsius. ${ }^{18}$ The remaining carbon budget is calculated to be 565 gigatonnes (billion tonnes) of $\mathrm{CO}_{2}$. Combusting the world's proven reserves of fossil fuels would emit around five times that amount: 2,795 gigatonnes of $\mathrm{CO}_{2} \cdot{ }^{19}$

11 See Intergovernmental Panel on Climate Change Working Group I Climate Change 2013: The Physical Science Basis: Summary for Policy Makers (2014); and Intergovernmental Group on Climate Change Working Group II Climate Change 2014: Impacts, Adaptation, and Vulnerability: Summary for Policy Makers (2014).

12 There are numerous greenhouse gases and the measurement unit is "carbon dioxide equivalents", which is a measure of their global warming potential relative to that of carbon dioxide. However, carbon dioxide is globally the most important greenhouse gas.

13 James Hanson and others "Target Atmospheric $\mathrm{CO}_{2}$ : Where Should Humanity Aim?" (2008) 2 The Open Atmospheric Science Journal 217-231.

14 US National Oceanic and Atmospheric Administration "Trends in Atmospheric Carbon Dioxide" Earth System Research Laboratory: Global Monitoring Division <www.esrl.noaa.gov>.

15 See Wogan, above n 10; and S Lovejoy "Scaling fluctuation analysis and statistic hypothesis testing of anthropogenic warming" (2014) 42 Climate Dynamics 2339.

16 United Nations Environment Programme The Emissions Gap Report 2014 (2014) at xv; and Adrian Macey "Climate Change: towards policy coherence" (2014) 10(2) Policy Quarterly 49 at 49.

17 Jon Hovi, Tora Skodvin and Stine Aakre "Can Climate Change Negotiations Succeed?" (2013) 1(2) Politics and Governance 138 at 139; and Ministry for the Environment New Zealand's Greenhouse Gas Inventory 1990-2012 (2014) at vi-vii.

18 Copenhagen Accord Decision 2/CP.15 in Report of the Conference of the Parties on its fifteenth session, held in Copenhagen from 7 to 19 November 2009: Addendum: Part Two: Action taken by the Conference of the Parties at its fifteenth session FCCC/CP/2009/11/Add.1 (2010) [Copenhagen Accord]. There is some argument that this maximum was a political compromise and that the scientific evidence points towards a maximum of 1.5 degrees Celsius. See Michelle Nijhuis "Is 2 Degrees the Right Limit for Global Warming? Some Scientists Say No" National Geographic (1 October 2014) <www.nationalgeographic.com>. If that is correct, the global carbon budget would be lower.

19 Carbon Tracker Initiative "Unburnable Coal - Are the world's financial markets carrying a carbon bubble?" (2012) Carbon Tracker <www.carbontracker.org>. 
For New Zealand's part, government estimates are that there are reserves of 15 billion tonnes of coal, ${ }^{20} 55$ million barrels of recoverable oil and 8,214 billions of cubic feet of recoverable gas. ${ }^{21}$ Combusting these fossil fuel reserves could generate approximately 26.3 gigatonnes of $\mathrm{CO}_{2}$, thereby exhausting 4.65 per cent of the global carbon budget. ${ }^{22}$ The mines at issue in this case, and the emissions that would be inevitable from their development, will contribute to the cumulative effects of climate change and of exhausting the global carbon budget.

\section{FACTUAL BACKGROUND}

A Commission appointed by the West Coast Regional and Buller District Councils granted land use consents to develop Buller Coal's Escarpment Mine on the Denniston Plateau. At about the same time, Solid Energy was looking to develop the Mount William North Mine. Each of these two mines were expected to produce 4.1 million tonnes of coal for export to steel manufacturing industries. The total greenhouse gas emissions from combusting 8.2 million tonnes of coal will be approximately 20 million tonnes. ${ }^{23}$

Since the coal would be exported and combusted overseas, air discharge permits were unnecessary. Instead, the consents applied for were land use consents. These were required for ancillary elements of the mines: roading; pipe works; a processing plant and handling facility; the construction of an electrical substation; and the use, storage and handling of hazardous substances. ${ }^{24}$

Conservation organisations, West Coast ENT and the Royal Forest and Bird Society, appealed the Commission's granting of consents for the Escarpment Mine on the ground that the Commission erred in not giving regard to the effects on climate change. In response, the mining companies applied for a declaration that decision makers who are considering applications for land use consents for activities associated with coal mining cannot have regard to the effects on climate

20 New Zealand Petroleum and Minerals "Welcome to Coal" Ministry of Business, Innovation and Employment <www.nzpam.govt.nz>.

21 Ministry of Business, Innovation and Employment "Energy Data File" (2014) <www.med.govt.nz>.

22 Calculations by the author based on emissions factors (EF per unit) in Ministry for the Environment Guidance for Voluntary Corporate Greenhouse Gas Reporting: Data and Methods for the 2012 Calendar Year (2014) at 8. For coal, 15 billion tonnes multiplied by EF 1.7 per tonne equals 25.8 billion tonnes of $\mathrm{CO}_{2}$ (1.7 is the default EF for coal). For oil, 55 million barrels multiplied by 158.9 litres per barrel multiplied by EF 2.94 per litre equals 25.7 million tonnes of $\mathrm{CO}_{2}$ (2.94 is the EF for light fuel oil). For gas, 8.214 billion cubic feet of gas is 8.792 .7 petajoules or 8,792,700,000 gigajoules multiplied by EF 52.8 per GJ equals 464.3 million tonnes of $\mathrm{CO}_{2}$ (52.8 is the $\mathrm{EF}$ for distributed natural gas).

23 Buller Coal Ltd $v$ West Coast Ent, above n 2, at [11]; and Royal Forest and Bird v Buller Coal, above n 4, at [1]. To put those emissions into perspective, an average car will produce around two tonnes of greenhouse gases per annum, and New Zealand's gross emissions in 2012 was 76,048 billion tonnes: New Zealand Transport Agency "Toyota Corolla GLX 2014 (current)" RightCar.govt.nz <www.rightcar.govt.nz>; and Ministry for the Environment New Zealand's Greenhouse Gas Inventory 1990-2012 (2014) at ix.

24 West Coast ENT Inc v Buller Coal Ltd, above n 1, at [104]. 
change of greenhouse gas emissions that arise within or outside New Zealand's territorial boundaries from the subsequent combustion of the coal extracted on reliance of those consents. ${ }^{25}$ That declaration was granted.

Conversely, the declaration that West Coast ENT applied for (but which was declined) was that decision makers must, under s 104(1), consider subsequent discharges of greenhouse gases from the combustion of the extracted coal and have particular regard, under s 7(i), to the effects of climate change. ${ }^{26}$ Section 7 (i) provides that decision makers "shall have particular regard to ... the effects of climate change". This provision was interpreted in the Environment Court and High Court as relating to adapting to climate change ("effects of climate change"), not mitigating the phenomenon ("effects on climate change"). ${ }^{27}$ The conservation organisations abandoned arguments based on $\mathrm{s}$ 7(i) in the Supreme Court. ${ }^{28}$

The remaining issue was the interpretation of ss 3, 70A and 104E of the Amendment Act. Section 3, which was not inserted into the Principal Act, provides:

3 Purpose

The purpose of this Act is to amend the principal Act-

(a) to make explicit provision for all persons exercising functions and powers under the principal Act to have particular regard to-

(i) the efficiency of the end use of energy; and

(ii) the effects of climate change; and

(iii) the benefits to be derived from the use and development of renewable energy; and

(b) to require local authorities-

(i) to plan for the effects of climate change; but

(ii) not to consider the effects on climate change of discharges into air of greenhouse gases.

Sections 70A and 104E were inserted into the Principal Act and they provide:

70A Application to climate change of rules relating to the discharge of greenhouse gases

... when making a rule to control the discharge into air of greenhouse gases under its functions under section 30(1)(d)(iv) or (f), a regional council must not have regard to the effects of such a discharge on

25 Buller Coal Ltd v West Coast Ent, above n 2, at [4].

26 At [5].

27 West Coast ENT Inc v Buller Coal Ltd, above n 1, at [130].

28 At [82]. 
climate change, except to the extent that the use and development of renewable energy enables a reduction in the discharge of greenhouse gases...

\section{E Applications relating to discharge of greenhouse gases}

When considering an application for a discharge permit or coastal permit to do something that would otherwise contravene section 15 or section $15 \mathrm{~B}$ relating to the discharge into air of greenhouse gases, a consent authority must not have regard to the effects of such a discharge on climate change, except to the extent that the use and development of renewable energy enables a reduction in the discharge into air of greenhouse gases ...

It is clear that ss $70 \mathrm{~A}$ and $104 \mathrm{E}$ prohibit consideration of greenhouse gases with respect to air discharge permits. This was affirmed by the decision of Greenpeace New Zealand Inc $v$ Genesis Power $L t d{ }^{29}$ In that case, an air discharge permit was at issue. Greenpeace argued that, under s 7(j), the decision maker should have had particular regard to the benefits to be derived from renewable energy developments. The development at issue was Genesis's proposed gas-fired electricity plant. In effect, Greenpeace was arguing that the emissions from the proposed fossil fuel electricity plant should have been compared to the emissions from a hypothetical renewable electricity plant. The Supreme Court's conclusion, however, was that s 104E only allowed discharges of greenhouse gas emissions to be considered in respect of renewable energy developments per se and not in respect of air discharge permits for other types of development. ${ }^{30}$ One basis for that conclusion was Parliament's intention "to ensure that the discharge of greenhouse gases was 'addressed using a national mechanism"'.31

In the present case, an air discharge permit was not applied for, so s 104E was not prima facie triggered and the Greenpeace decision could be distinguished. The issue, therefore, was whether the Amendment Act had been comprehensive in prohibiting the consideration of greenhouse emissions (except in relation to renewable energy developments). ${ }^{32}$ If not, then the climate change effects from the end use of activities needing other types of resource consent would remain to be considered under s 104(1)(a). Section 104 provides:

\section{Consideration of applications}

(1) When considering an application for a resource consent and any submissions received, the consent authority must, subject to Part 2, have regard to-

29 Greenpeace New Zealand Inc v Genesis Power Ltd [2008] NZSC 112, [2009] 1 NZLR 730.

30 At [65].

31 At [59] (footnote omitted).

32 For readability, it will not be repeated that there is the statutory exemption in ss 70A and 104E that permits consideration of the avoidance of greenhouse gas emissions from renewable energy developments. 
(a) any actual and potential effects on the environment of allowing the activity;

(2) When forming an opinion for the purposes of subsection (1)(a), a consent authority may disregard an adverse effect of the activity on the environment if a national environmental standard or the plan permits an activity with that effect.

\section{THE PURPOSIVE INTERPRETATION}

A major aspect of the majority's judgment was testing a literal interpretation of s 104E by applying it to six hypothetical scenarios. ${ }^{33}$ In each hypothetical, discharges of greenhouse gases were separate to some other element of an activity. To illustrate, one hypothetical was a concurrent application to mine and burn coal, in which the emissions could not be considered with the application to burn the coal, but could be considered with respect to the mining. ${ }^{34}$ In all of the scenarios, discharges to air could be considered, not by an air discharge permit, but by the side-route of the second matter. Such results, the majority concluded, "would subvert the scheme of the [Amendment Act] which leaves climate change effects to the national government and would thus deprive s $104 \mathrm{E}$ of practical effect". ${ }^{35}$ This finding meant that the issue fell to be determined by how the provisions should be interpreted in light of the purpose of the RMA as amended. The preliminary issue, then, was defining that purpose.

To do that in this analysis, the two definitions of purpose identified by the Supreme Court are described in Section A. Following that, fundamental principles of purposive interpretation are summarised in Section B. Then, in Sections C-F, a range of matters internal and external to the RMA are analysed to identify the purpose and what light it casts upon the meaning and effect of the Amendment Act.

\section{A Duelling Conclusions}

As already said, the majority concluded that the purpose and effect of the Amendment Act was to completely remove the ability of consent authorities to regulate activities by reference to their greenhouse gas emissions. To reach that conclusion, seven key topics were explored. First was the role of the CCRA, which was deemed to be "the machinery" for complying with international obligations $^{36}$ and "left little - and arguably no - scope for useful involvement by local authorities". ${ }^{37}$ Secondly, whilst accepting that activities' consequential effects can be considered,

33 West Coast ENT Inc v Buller Coal Ltd, above n 1, at [157]-[169].

34 At [157]-[158].

35 At [169].

36 At [101] (emphasis added).

37 At [127]. 
this is a question "of fact and degree". ${ }^{38}$ In the present case, "there would always have been scope for argument" that downstream effects on climate change were too remote from the particular activities at issue. ${ }^{39}$

The third aspect related to the coal being combusted overseas. The majority did not attempt to resolve this issue and simply noted Whata J's conclusion in the High Court that the RMA does not confer jurisdiction to regulate activities extraterritorially. ${ }^{40}$

The fourth point was "tangibility". ${ }^{41}$ According to the majority, "there would have been considerable scope" for arguing whether the effects on climate change of burning coal would be sufficiently tangible for triggering s 104(1)(a) even before the 2004 Amendment Act. ${ }^{42}$ This was because the coal would supply an existing market which would have sourced coal from other suppliers if they were unable to source New Zealand coal. On this assumption, there would be no "appreciable difference" to global coal consumption. ${ }^{43}$ Furthermore, "it would be difficult, and probably impossible, to show that the burning of coal would have any perceptible effect on climate change". ${ }^{44}$ That said, the majority did discuss the counter arguments that would rest on the definition of "effects" and "cumulative effects" under s 3 of the Principal Act. ${ }^{45}$

Fifthly, the majority summarised the scheme of the RMA as relevant to the Amendment Act and brought particular attention to the following features:

(a) the hierarchy of policies and standards: national regulations take precedence over regional, which take precedence over territorial; 46

(b) the prohibition of industrial discharges into air except where expressly allowed by national or regional instruments; ${ }^{47}$ and

(c) the functions of territorial authorities, such as the Buller District Council, which do not extend to regulating discharges of contaminants into air. ${ }^{48}$

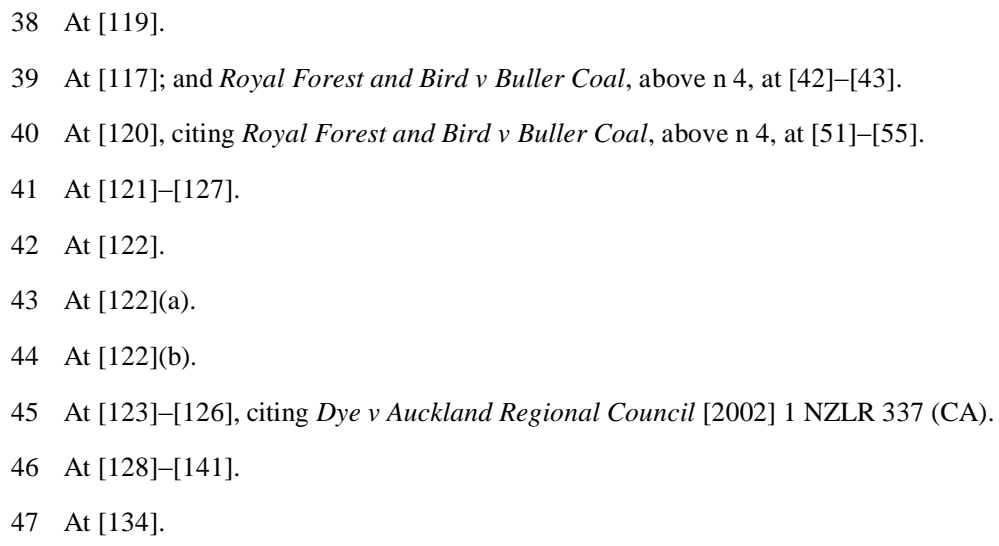


Sixthly, various aspects of the legislative history of the Amendment Act were set out, ${ }^{49}$ but the majority downplayed its usefulness because "unfortunately ... it gives some mixed signals". 50

Finally, the majority set out the six hypothetical scenarios noted above and concluded that "a literal interpretation of s 104(1)(a) would produce anomalous outcomes". 51

The majority does not state which specific provision or provisions its decision is based upon. It is virtually certain, however, that the text of ss $70 \mathrm{~A}$ and $104 \mathrm{E}$ is relied on and expanded to encompass all types of resource consent. This is because the majority refers to the possibility that those responsible for drafting the amendment "assumed the climate change arguments could only be advanced in relation to rules and consents involving direct discharges". ${ }^{52}$ It also seems highly unlikely that the majority would have directly applied s $3 . .^{53}$

The different purpose and scheme approach of Elias CJ led to her defining the effect of the Amendment Act as creating discrete exclusions from when greenhouse emissions could be considered. This conclusion was reached, first, by considering the Amendment Act in light of pt 2 of the Principal Act. The range of matters to be considered under pt 2 - especially the purpose of "sustainable management" 54 - is unrestricted. Therefore, the activities being consented could not properly be characterised as "ancillary" to the "overall mining proposal" and decision makers should not be blinkered from assessing effects of end use. ${ }^{55}$

Secondly, Elias CJ found that no issue of overseas jurisdiction arose because the activities being consented were within New Zealand and because of the global effects of climate change. ${ }^{56}$ Thirdly, Elias CJ considered the workings of s 104: although neither local regulation nor discharge consent was at issue, that does not impose exclusions of considerations under s 104(1)(a), which refers to "any 'adverse effect of the activity"'. ${ }^{57}$ According to Elias CJ, there was no absurdity or gap that

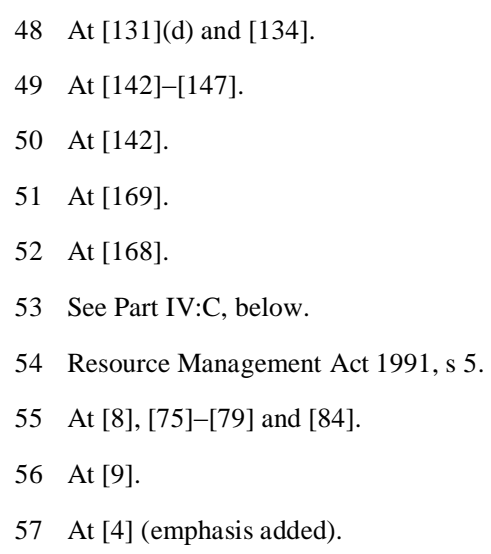


justified reading in an exclusion to all considerations of greenhouse gases and doing so would be a "substantial gloss" on the RMA as a whole. ${ }^{58}$

Fourthly, Elias CJ surveyed materials relevant to the legislative history of the Amendment Act and concluded that it was not intended to be comprehensive in its exclusionary effect on climate change considerations. Instead, an objective was to provide a stronger mandate to consider climate change matters. 59

Finally, Elias CJ deemed s 104E to be not directly relevant to the present case and that national management of emissions covered by that provision did not neutralise adverse effects on the environment for the purposes of considering other consent types. ${ }^{60}$

The duelling interpretations of the purpose of the amended RMA were at the heart of the decision, so critiquing the judgment requires examining the purpose afresh.

\section{B Purposive Interpretation Generally}

Purposive interpretation is, of course, the main method of modern statutory interpretation. ${ }^{61}$ Section 5 of the Interpretation Act 1999 stipulates that meaning is derived from a statute's "text" and "in the light of its purpose". These two elements create a tension, whereby purpose may be constrained by words, but words' meanings may be expanded to effectuate Parliament's intention. ${ }^{62}$ The Supreme Court has unanimously emphasised that, even when other methods of statutory interpretation are employed or where meaning appears plain, there "should always be cross[checking] against purpose". ${ }^{63}$

Two important limits are worth noting. The first is the constraints of a provision's text: "there is only so far one can 'stretch' the meaning of words" before crossing the constitutional boundary into rewriting text. ${ }^{64}$ Correcting drafting errors and filling gaps in a statute are permissible but only in

58 At [23]-[24] and [72]-[75].

59 At [24], [60]-[68] and [85].

60 At [70]-[71].

61 JF Burrows and RI Carter Statute Law in New Zealand (4th ed, LexisNexis, Wellington, 2009) at 205-206, citing $R$ (on the application of Quintavalle) v Secretary of State for Health [2003] 2 All ER 113 (HL) at [21]; and Attorney-General's Reference (No 5 of 2002) [2004] 4 All ER 901 (HL) at [31].

62 George Tanner and Ross Carter "The Old Girl Still Looks Good to Me: Purposive Interpretation of New Zealand Legislation" (paper presented to the 4th Australasian Drafting Conference, Sydney, August 2005) at 66; and see Burrows and Carter, above n 61, at 201.

63 Commerce Commission v Fonterra Co-operative Group Ltd [2007] NZSC 36, [2007] 3 NZLR 767 at [22] per Tipping J; and see MD Foods plc (formerly Associated Dairies Ltd) v Baines and others [1997] AC 524 at 532, per Lord Nicholls.

64 Burrows and Carter, above n 61, at 225. 
the rarest of circumstances. ${ }^{65}$ The second limit is that, whilst "[t]he duty of the Court must be to attach significance to and obtain help from" a purpose provision, ${ }^{66}$ its language is often compressed and unable to embody the full précis of the statute. ${ }^{67}$

Noting the benefits and limitations, the purposive approach is necessary to understand the true nature and scope of the 2004 Amendment Act provisions.

\section{Reconciling Conflicting Purposes}

Purposive interpretation is sometimes employed to resolve conflicts between provisions within the same enactment. Here, however, we are uniquely confronted by having two purpose provisions relevant to the same enactment which conflict. On the one hand, we have the Principal Act's purpose of "promot[ing] the sustainable management of natural and physical resources". 68 On the other, we have the Amendment Act's purpose of "requir[ing] local authorities ... not to consider the effects on climate change of discharges into air of greenhouse gases". ${ }^{69}$ Climate change is already impacting on natural and physical resources domestically and globally, and those effects will intensify as the phenomenon continues to be aggravated. ${ }^{70}$ A reader does not need to be a scientist to see that, relative to pt 2 of the RMA, climate change risks undermining the reasonably foreseeable needs of future generations and the life-supporting capacity of water, soil and ecosystems, as well as the natural character of the coastal environment, wetlands, outstanding natural features, and indigenous flora and fauna. ${ }^{71}$ The question, then, is how might we resolve this conflict?

Establishing "the" purpose of the RMA relative to the Amendment Act is not necessarily a matter of choosing "one or the other". Instead, it is proposed here that the interpreter's role is to first try to reconcile the two purposes. In $R v$ Pora regarding conflicting operative provisions, Elias CJ said: ${ }^{72}$

65 Susan Glazebrook "Filling the Gaps" in Rick Bigwood The Statute: Making and Meaning (LexisNexis, Wellington, 2004) 153 at 163. The issue of adding words is discussed in Part VI below.

66 Ashburton Acclimatisation Society v Federated Farmers of New Zealand Inc [1988] 1 NZLR 78 (CA) at 88 per Cooke P.

67 Dominion Air Lines, Ltd (in liq) v Strand [1933] NZLR 1 (SC) at 45.

68 Resource Management Act 1991, s 5.

69 Resource Management (Energy and Climate Change) Amendment Act 2004, s 3(b)(ii).

70 See Intergovernmental Panel on Climate Change Working Group II, above n 11; and Luke Harrington "The role of anthropogenic climate change in the 2013 North Island drought" (16 October 2014) New Zealand's Low-Emission Future: Blog run by Motu and NZCCRI <www.low-emission-future.blogspot.co.nz>.

71 Sections 5(2) and 6(a)-(d); and see Intergovernmental Group on Climate Change Working Group II, above n 11, at 15-18.

$72 R$ v Pora [2001] 2 NZLR 37 (CA) at [4] per Elias CJ. 
If the provisions can be reconciled, the meaning which lets them work together is preferred. If they cannot be reconciled, the Court has to determine which must give way.

Also in $R v$ Pora, Thomas $\mathrm{J}$ found that both of the conflicting provisions should be interpreted, not just the one which came later in time: ${ }^{73}$

To my mind, it is not legitimate to focus exclusively on s 2(4) [of the later-in-time Criminal Justice Amendment Act (No 2) 1999]. Of course, the meaning of s 2(4) is to be ascertained from its text and in the light of its purpose. But the same approach must be accorded to s 4(2) [of the earlier Criminal Justice Act 1985]. The meaning of that subsection must also be ascertained from its text and in the light of its purpose.

Without authority on resolving two internally conflicting purpose provisions, these principles from $R v$ Pora will be applied in an attempt to reconcile s 3 of the Amendment Act and pt 2 of the Principal Act, particularly s 5.

The relevant component of the Amendment Act is s 3(b)(ii), which provides:

The purpose of this Act is to amend the principal Act ... to require local authorities ... not to consider the effects on climate change of discharges into air of greenhouse gases.

In the Principal Act, s 5(1) states that the purpose of the RMA is "to promote the sustainable management of natural and physical resources". Section 5(2) then defines "sustainable management" as:

... managing the use, development, and protection of natural and physical resources in a way, or at a rate, which enables people and communities to provide for their social, economic, and cultural wellbeing and for their health and safety while-

(a) sustaining the potential of natural and physical resources (excluding minerals) to meet the reasonably foreseeable needs of future generations; and

(b) safeguarding the life-supporting capacity of air, water, soil, and ecosystems; and

(c) avoiding, remedying, or mitigating any adverse effects of activities on the environment.

The purposes and principles of the RMA, pt 2, continue with s 6, which sets out matters of national significance for which decision makers "shall recognise and provide for". Section 7 then lists certain "other matters" that decision makers "shall have particular regard to", and s 8 provides that persons exercising functions under the Act "shall take into account the principles of the Treaty of Waitangi". 74

73 At [127] per Thomas J.

74 It is outside the scope of this article to explore any implications of climate change measures on the principles of the Treaty, such as active protection. 
The majority did not explore any conflict or relationship between the two purpose provisions. On s 3 alone, the majority said, "[i]f the purpose expressed in s 3 had been explicitly carried through to the operative provisions of the 2004 Amendment Act this would have disposed of the appellant's argument. ${ }^{175}$ Indeed that would be so since the language of s 3 is patently clear, albeit a very broad brush. However, its broad brush language is "only" contained in a purpose provision that was not carried through to the Principal Act, so that leaves its precise effect unclear. As Ostler $\mathbf{J}$ has cautioned: ${ }^{76}$

Statutes constantly provide for matters not referred to in their Short Titles, and it is impossible in the compressed language in which the Short Title of an Act is expressed to embody a compendious précis of the whole of its provisions.

This guidance is pertinent since we would not expect an enactment's purpose provision to be applied literally. That said, the majority's only other reference to s 3 is noting that the mining companies' counsel pointed to $\mathrm{s} 23$ of the Interpretation Act: "An amending enactment is part of the enactment that it amends."77 There is no discussion on any effect of this correlation but one might infer from the majority's carte blanche expansion of the application of ss 70A and 104E that s 3 was read literally as an operative provision. If so, there are flaws with this approach. First, s 3 is a purpose provision so its function is limited to casting light on the meaning of text. ${ }^{78}$ Secondly, there is no evidence in the Amendment Act nor its legislative history that Parliament intended to alter the purpose of the RMA by limiting the sustainable management objective nor the mandatory considerations in ss 6 to $8 .^{79}$ Thirdly, the conflict between s 3 and s 5 ought to have been identified and reconciled, as per $R v$ Pora. Fourthly, $\mathrm{s} 3$ itself, as well as those operative provisions at issue, ought to have been interpreted in light of $s$ of the Principal Act.

The importance of s 5 is undeniable. Recently, its role was discussed at length by a differently constituted Supreme Court in Environmental Defence Society v New Zealand King Salmon (EDS v King Salmon). ${ }^{80}$ The Court said, inter alia:

75 West Coast ENT Inc v Buller Coal Ltd, above n 1, at [97].

76 Dominion Air Lines Ltd (in liq) v Strand, above n 67, at 45 per Ostler J

77 West Coast ENT Inc v Buller Coal Ltd, above n 1, at [140].

78 Interpretation Act 1999, s 5(1); and see Burrows and Carter, above n 61, at 219-220.

79 Indeed, the considerations in s 7 were expanded by adding considerations: ss 7(ba) ("the efficiency of the end use of energy"), 7(i) ("the effects of climate change") and 7(j) ("the benefits to be derived from the use and development of renewable energy"). See West Coast ENT Inc v Buller Coal Ltd, above n 1, at [58] and [82]-[83].

80 Environmental Defence Society Inc v New Zealand King Salmon Company Ltd [2014] NZSC 38, [2014] NZRMA 195. 
- $\quad$ the obligation of those who perform functions under the RMA to comply with the statutory objective is clear";

- $\quad$ "Section 5 is a carefully formulated statement of principle intended to guide those who make decisions under the RMA"; and

- $\quad$ "Section 5 sets out the core purpose of the RMA". ${ }^{81}$

Critically, the majority in EDS $v$ King Salmon concluded that sustainable management is an objective to be met, not merely a guide to interpretation, and so environmental bottom lines are legitimate: 82 "the RMA envisages ... a cascade of planning documents, each intended, ultimately, to give effect to $\mathrm{s} 5{ }^{83}$

Notwithstanding its paramount importance, the majority in West Coast $v$ Buller did not refer to $\mathrm{s}$ 5 at all, other than when setting out the scheme of the RMA. Sections 6-8 were not referred to either, except for discounting the relevance of s 7(i). There is no attempt in the majority's judgment to interpret either the purpose or operative provisions of the Amendment Act in light of the purpose of the Principal Act.

It is contended here that, by omitting reference to $\mathrm{s} 5$, the majority's approach was inconsistent with $\mathrm{s} 5$ of the Interpretation Act and with the approach to the same provision in the subsequent $E D S v$ King Salmon decision. The only potential reason for ignoring a purposive approach was if the literal meaning was clear, but that was emphatically rejected by the majority via their hypothetical examples. It was not sufficient to interpret ss $70 \mathrm{~A}$ and $104 \mathrm{E}$ only in light of the purpose of the Amendment Act. Rather, the Amendment Act should have also been read in light of the purpose and principles of the Principal Act.

As for relying solely on s 3 of the Amendment Act for purposive interpretation, which is what appears to be the basis of the majority's reasoning, there is no evidence s 3 was intended to affect the purpose of the Principal Act. For these reasons, this analysis agrees with the conclusion of Elias $\mathrm{CJ}:{ }^{84}$

I doubt whether s 3 is properly to be treated as part of the Resource Management Act because it does not itself amend the Act. The provisions that amend are carried into the principal Act. And s 3 is relevant to their interpretation. To the extent that the amending provisions affect the scheme of the Act, s 3 is relevant also in understanding that change in scheme. But it is otherwise spent. Nor does s 3, properly construed in the light of the substantive amendments made by the 2004 Amendment Act, affect the meaning of s 104(1)(a) or the scheme of the Resource Management beyond those substantive changes.

81 At [21], [25] and [26].

82 At $[24](a)$.

83 At [30].

84 West Coast ENT Inc v Buller Coal Ltd, above n 1, at [86]. 
Section 3 casts light on ss 70A and 104E, but pt 2 of the RMA is unaffected. The result, therefore, is that ss $70 \mathrm{~A}$ and $104 \mathrm{E}$ must also be read in light of pt 2 . The only way, therefore, to reconcile the inherent conflict between ss 3 and 5 is to afford to s 5 the primacy it takes in the Act and to read a narrow interpretation of the amendment provisions in the light that $\mathrm{s} 5$ casts.

\section{The Legislative History of the Amendment Act}

As well as reading the amendments in light of s 5, it is legitimate to identify the mischiefs that Parliament was trying to address with the Amendment Act. ${ }^{85}$ The Explanatory Note to the Bill, the Select Committee Report and Hansard appeared to the majority to give mixed signals. ${ }^{86}$ In theory, exploring legislative history is generally limited to these sources. ${ }^{87}$ Indeed, anything else might be criticised for "delv[ing] into the mind of the legislators or their draftsmen, or committee members" for subjective rather than objective purpose. ${ }^{88}$ However, there is more data available to discover Parliament's intention with the Amendment Act and: ${ }^{89}$

In interpreting an Act of Parliament, it is proper, and indeed necessary, to have regard to the state of affairs existing, and known by Parliament to be existing, at the time. It is a fair presumption that Parliament's policy or intention is directed to that state of affairs.

In a subsequent judgment by a differently constituted majority, the Supreme Court in Allied Concrete Ltd $v$ Meltzer and Hayward thoroughly endorses the importance of reference to legislative history and context by setting it out at length and relying on it throughout its judgment. ${ }^{90}$

Indicators of Parliament's intention with the Amendment Act can be found in the state of affairs existing at the time as well as the materials that are examined more commonly for identifying that intention.

The Amendment Act was enacted roughly half way through the nine years of the Fifth Labour Government (1999-2008). Under the new all-of-government brand, Sustainability.govt.nz, a range of policies were implemented to reduce New Zealand's greenhouse emissions and to fulfil commitments under the 1998 Kyoto Protocol. These included the Energy Efficiency and

85 Marac Life Assurance Ltd v Commissioner of Inland Revenue [1986] 1 NZLR 694 (CA); and New Zealand Maori Council v Attorney-General [1987] 1 NZLR 641 (CA).

86 West Coast ENT Inc v Buller Coal Ltd, above n 1, at [142].

87 See Rajamani $v R$ [2007] NZSC 68, [2008] 1 NZLR 723 at 729; and Marac Life Assurance Ltd $v$ Commissioner of Inland Revenue, above $\mathrm{n} 85$, at 701.

88 Felix Frankfurter "Some Reflections on the Reading of Statutes" (1947) 47 Colum L Rev 527 at 538-539, cited in Glazebrook, above n 65, at 157-158.

89 Royal College of Nursing of the UKv Department of Health and Social Security [1981] AC 800 (HL).

90 Allied Concrete Ltd v Meltzer and Hayward [2015] NZSC 7, (2015) 10 NZBLC 99-717. 
Conservation Act 2000 (EEC Act), from which came the first National Energy Efficiency and Conservation Strategy (NEECS). ${ }^{91}$ In its Foreword, the Minister of Energy, Hon Pete Hodgson MP, said, "New Zealand's commitment to honour the Kyoto Protocol on greenhouse gas reductions reinforces just how important the strategy is to our overall climate change response". 92 One of the programme outcomes in the NEECS was to identify changes to the RMA to give greater prominence to sustainable energy and to investigate "sustainable urban form". ${ }^{93}$ Other programmes delivered through the NEECS were targeted at working with local government to reduce greenhouse emissions from their councils' operations and from their communities. ${ }^{94}$ It is evident that activities requiring resource consents (other than discharge to air permits) were anticipated to be leveraged to influence New Zealand's greenhouse emissions.

Other central government policies had specific objectives for reducing greenhouse emissions and were also directly relevant to local government decision making. The New Zealand Waste Strategy 2002, for example, had targets to reduce organic waste (which creates methane when decomposing), ${ }^{95}$ and the New Zealand Transport Strategy 2002 aimed for a "sustainable transport system". 96 The Transport Strategy was produced under authority of the Land Transport Act 1988 and was a mandatory consideration for the development of regional land transport strategies along with the NEECS. ${ }^{97}$

The main component of the Fifth Labour Government's suite of climate change policies was the CCRA. Its original purpose was only to ratify the United Nations Framework Convention on Climate Change (UNFCCC) and the Kyoto Protocol. ${ }^{98}$ It was envisaged that the CCRA would be

91 Energy Efficiency and Conservation Act 2000, ss 8-12; and Energy Efficiency and Conservation Authority and Ministry for the Environment National Energy Efficiency and Conservation Strategy: Towards a sustainable energy future (September 2001).

92 Energy Efficiency and Conservation Authority and Ministry for the Environment, above n 91, at 1.

93 At 3, 12, 14 and 16

94 Ministry for the Environment "Annual Report on Climate Change Policy Implementation" (2004) <www.mfe.govt.nz>; and Diana Shand "Communities for Climate Protection - New Zealand: Where the rubber hits the road: From policy to action" (presentation to Climate Change: the Policy Challenges Symposium, Wellington, October 2006).

95 Ministry for the Environment Review of Targets in the New Zealand Waste Strategy (2004).

96 Ministry of Transport New Zealand Transport Strategy (2008) at 2; and Ministry for the Environment, above $\mathrm{n} 94$.

97 Land Transport Act 1988, ss 170-174 and 175(2)(c).

98 Climate Change Response Act 2002, s 3; United Nations Framework Convention on Climate Change 1771 UNTS 107 (opened for signature 4 June 1992, entered into force 21 March 1994) [UNFCC]; and Kyoto Protocol to the United Nations Framework Convention on Climate Change 2303 UNTS 1 (opened for signature 11 December 1997, entered into force 16 February 2005) [Kyoto Protocol]. 
amended later to provide for the implementation of preferred policy measures that were still under consideration at that time. ${ }^{99}$

This state of affairs existed and, given the use of legislation, was known by Parliament to be existing at the time of the Amendment Act. ${ }^{100}$ It provides contextual data for interpreting the legislative history's "mixed signals". ${ }^{101}$

Along with that state of affairs, the Explanatory Note to the Bill offers particular insights into Parliament's intention. The Bill, it says, had three objectives: to support renewable energy and energy efficiency; to support climate change adaptation measures; and "to remove climate change as a consideration when considering industrial discharges of greenhouse gas emissions, as these emissions are best addressed using a national mechanism". ${ }^{102}$ The third objective was responding to a lack of clarity on the role of regional councils, ${ }^{103}$ which would be solved by "remov[ing] explicitly the ability of regional councils to control emissions ... [so] that emitters only face controls on their emissions as a result of national instruments". ${ }^{104}$ However, such removal was deliberately limited; not comprehensive: ${ }^{105}$

[T] he objective is to clarify that, although ... all those acting under the RMA have energy and climate change responsibilities, it is most appropriate to specifically address industrial discharges at the national level. The ability to control land uses for climate change purposes remains unchanged.

Indeed, the Explanatory Note shows that the intention was to create "a stronger legal mandate to take into consideration ... climate change matters". ${ }^{106}$

Originally as drafted, the Bill would excise emissions considerations for industrial and trade premises. ${ }^{107}$ This reference was removed at the select committee phase because of submitters' concerns that certain other emissions might still be controlled by regional councils. That said, the Select Committee Report still stated that the "new sections 70A and 104E [would] prohibit regional

99 Vernon Rive "New Zealand Climate Change Regulation" in Alastair Cameron (ed) Climate Change Law and Policy in New Zealand (LexisNexis, Wellington, 2011) 165 at 187.

100 Royal College of Nursing of the UKv Department of Health and Social Security, above n 89.

101 West Coast ENT Inc v Buller Coal Ltd, above n 1, at [142].

102 Resource Management (Energy and Climate Change) Amendment Bill 2003 (explanatory note) [Amendment Bill 2003 (explanatory note)] at 1 (emphasis added).

103 At 4 .

104 At 7.

105 At 5 .

106 At 3-5 (emphasis added).

107 See (5 August 2003) 610 NZPD 7583 per Pete Hodgson. 
councils from having regard to the effects of discharges of greenhouse gases in specified circumstances". ${ }^{108}$ Those "specified circumstances" were presumably non-industrial and trade premises that still required an air discharge consent, given the remaining specificity of the new provisions, and given that those emissions sources were also envisaged to be subjected to a national emissions management regime.

In the Second Reading of the Bill, Hon Judith Tizard MP, speaking on behalf of the Convenor of the Ministerial Group on Climate Change, Hon Pete Hodgson MP, said "the Government's preference for national control of greenhouse gas emissions does not result in emitters facing duplication of controls". ${ }^{109}$ Whilst the specific reference to industrial and trade premises was removed, the mischief that was still being targeted was that potential for double regulation: the potential for those emitters who would be subject to national regulation of emissions to also be regulated by reference to their emissions via the RMA.

When the majority stated that the parliamentary history materials give "some mixed signals", this may refer to statements in the Explanatory Note such as: ${ }^{110}$

\footnotetext{
New section $70 A$ removes the power of regional councils, in making rules on the discharge of greenhouse gases into air, to have regard to the effects of a discharge on climate change.
}

$\cdots$

New section $104 \mathrm{~F}$ precludes a consent authority, when considering applications for discharges otherwise prohibited by section 15 or section $15 \mathrm{~B}$, from having regard to the effects of a discharge on climate change.

However, it appears that these statements are simply suffering from generality and imprecision, and are not intended to superimpose a far broader meaning than what is specified in terms of the mischiefs that the amendments would manage. It is clear - from the specificity of the statements in the legislative history, plus the state of affairs known at the time, plus the text of ss 70A and 104E that the mischiefs being addressed were: first, the need to promote renewable energy (and therefore avoid or replace energy derived from fossil fuels); secondly, the need to enable councils to adapt to climate change; thirdly, to address uncertainty and potential inconsistency about regional management of emissions of a scale that necessitates an air discharge permit; and fourthly, to avoid double regulation via both the RMA and some forthcoming national regulation measure (which later became the emissions trading scheme (ETS)).

108 Resource Management (Energy and Climate Change) Amendment Bill (select committee report) at 6 (emphasis added).

109 (17 February 2003) 615 NZPD 11040 per Judith Tizard (emphasis added); and see Amendment Bill 2003 (explanatory note), above n 102, at 7 .

110 Amendment Bill 2003 (explanatory note), above n 102, at 2. 


\section{E The Climate Change Response Act 2002}

As the Amendment Act was making its way through the legislative process, Parliament was also trying to decide what mechanisms would be put in place to meet New Zealand's Kyoto obligations. The CCRA in its original form ratified the Protocol and established the framework, powers and institutions needed for New Zealand to fulfil its Kyoto obligations. ${ }^{111}$ It did not set up a carbon tax or an ETS at that time. The carbon tax, which was developed as part of a policy package but not legislated for, was intended to apply to emissions from energy supply and use, process emissions and fugitive emissions. ${ }^{112}$ It was only in 2005 - after the 2004 Amendment Act - that the tax option was abandoned in favour of the ETS, which then was enacted later in 2008. ${ }^{113}$

If we consider the application of the carbon tax as originally envisaged, the language is different - energy supply and use, process emissions and fugitive emissions - but it points very much towards the original scope of the 2004 Amendment Act: industrial and trade premises.

The evidence suggests that the considerations carved out from the RMA were intended to mirror those emissions sources that would be regulated by the national instrument: the gap carved out of regional regulation would be filled by national regulation. We know that the gaps created in the "sustainable management" considerations were meant to be filled because, in the Explanatory Note to the Bill, there is specific mention made of the risk of a "policy vacuum prior to national price mechanisms taking effect" and how those risks were mitigated. ${ }^{114}$

\section{F An Alternative Interpretation of Purpose}

On this analysis, it seems Elias CJ's approach to purposive interpretation was closer to Parliament's intention. Section 3 of the Amendment Act is a guide to interpretation but anything resembling a literal application of its broad language would be out of kilter with Parliament's intention, since the effect of that would be to scale down efforts to mitigate emissions. After New Zealand became a party to the 1998 Kyoto Protocol, Parliament was ramping up efforts to mitigate emissions. The CCRA was intended to be the central pillar of climate change policy, but not the whole edifice. Its primary place would be complemented by the RMA, the Energy Efficiency and Conservation Act 2000 and a range of executive-level strategies and programmes, some of which had statutory bases. To be complementary, the possibility of double regulation via the RMA and CCRA was to be avoided. To achieve this, consent authorities could no longer regulate greenhouse emissions from point-source activities that would be subjected to national regulation. They would,

111 Climate Change Response Bill 2002 (explanatory note).

112 Rive, above n 99, at 172.

113 At $187-188$.

114 Amendment Bill 2003 (explanatory note), above n 102, at 9-10. 
however, remain able to regulate other activities by reference to their addition or avoidance of emissions.

The fact that the coverage of the ETS does not precisely mirror the RMA excision cannot be resolved by judicial interpretation: the ETS is a moving target and any gaps or overlap with the RMA are for Parliament to resolve.

\section{THE SCHEME OF THE RMA}

\section{A Ancillaries and Absurdities}

The primary concern of the majority was that: ${ }^{115}$

... the literal approach [to ss 70A and 104E] would allow arguments which are off limits in relation to the issues which they are most closely related (namely, discharges to air) to come in, by the backdoor, in respect of ancillary issues (such as land use, roading and the like).

So, to avoid this "absurdity", 116 the majority deemed it necessary to remove all regulation by reference to greenhouse emissions. In contrast, Elias CJ thought "it would be misleading to characterise [these activities] as 'ancillary' or 'collateral"' and would have permitted the s 104(1)(a) assessment to examine the effects of end use. ${ }^{117}$

The mines were undoubtedly the purpose of all the activities that Buller Coal and Solid Energy were seeking consents for, and for that reason I respectfully disagree with Elias CJ. I believe it is accurate to describe access roads, substations and the like as ancillary: whilst they are essential elements of the development, they are not its purpose. Buller Coal and Solid Energy are not in the business of building roads and substations and would not have had an interest in undertaking those activities if it were not for the mines. Regulating a primary activity via consents for ancillary activities would, in my view, thwart Parliament's intention to avoid double regulation.

\section{B A Nuanced Solution: Background}

However, a nuanced approach to the RMA's scheme could have avoided "back door" regulation without throwing the champagne out with the cork. Before describing the approach being proposed here, relevant background matters need to be set out, including a very brief survey of the potential roles local government have with respect to mitigating greenhouse emissions.

The first relevant context is the uncontested law. Regional councils cannot, as per s 70A, make rules about discharges of greenhouse gases, nor can they consider the effects of greenhouse gases on climate change when assessing air discharge permit applications, as per s 104E. Territorial

115 West Coast ENT Inc v Buller Coal Ltd, above n 1, at [169].

116 At [171].

117 At [8]. 
authorities cannot make rules or assess the effects of any discharges of contaminants to air, by virtue of their competence not extending to discharges of contaminants to air as per s 31 .

Irrespective of these points, courts and consent authorities had - before and after the Amendment Act, but before the West Coast ENT Inc v Buller Coal Ltd decision - considered greenhouse emissions from activities that were not point-sources requiring air discharge permits. The emissions considered arose from polluting behaviours that were encouraged by activities for which consents were sought, for example, increased traffic emissions from the development of a shopping complex or office building. ${ }^{118}$ The risk of double regulation was irrelevant because applicants in such circumstances were not the subject of central government regulation via the CCRA; they were only the subject of local RMA regulation. Shoppers' increased petrol consumption relates to the CCRA, as that affects suppliers of liquid fossil fuels and ultimately their consumers, but it does not affect a shopping complex developer. ${ }^{119}$ Therefore, RMA rules and assessment considerations could have pertained to diffuse emissions in such circumstances without double regulation.

Emissions considerations might also have pertained to, not just projects that generated emissions, but also to projects that mitigated emissions. A resource consent applicant could have sought credit under s 3 of the Principal Act ("meaning of effect") for developments that mitigate emissions, such as converting land from a source of emissions (for example, a ruminant animal farm) to a use with lower emissions (for example, a subdivision) or to a carbon sink (for example, to forestry). Consideration of greenhouse gases in scenarios such as these would not have created any "absurd" outcomes. Quite the opposite, in fact, as it would have been consistent with the ethos underpinning the allowance for considering avoided emissions resulting from renewable energy developments and with Parliament's intention to ramp up mitigation efforts in light of New Zealand's obligations at international law.

These examples give a small insight into how many sources of greenhouse emissions local government can influence: ${ }^{120}$ via waste, transport, renewable energy, economic development, district planning and vegetation management. The majority may not have been made aware of this potential before it commented that the CCRA leaves "little - and arguably no - scope for useful involvement by local authorities". ${ }^{121}$ The majority may not have been made aware of the global

118 Merton v Rodney District Council EnvC Auckland A8/2007, 2 February 2007 at [33] and [49]. See also AMI Ltd v Christchurch City Council [2009] NZEnvC 100 at [97].

119 Climate Change Response Act 2002, sch 3, pt 2.

120 The potential for emissions mitigation via local government is alluded to in the Energy Efficiency and Conservation Act 2000, s 13(2)(a)(iv), which requires the Minister to consult with local authorities when drafting a national energy efficiency and conservation strategy.

121 West Coast ENT Inc v Buller Coal Ltd, above n 1, at [127]. 
impetus to support local government-level mitigation measures, such as the United Nations' Cities for Climate Change Initiative, the C40 Cities Climate Leadership Group (an international network of cities and mayors tackling emissions) and the Low-Carbon City programme. ${ }^{122}$

Given the potential, would it have been possible, in the scheme of the amended RMA, for councils to have made rules and assessed greenhouse emissions in such circumstances whilst avoiding the "back door" absurdity? A two-step process is required: first, identifying the greenhouse emissions outcomes as part of identifying potential effects; and secondly, defining the "development as a whole" to bring ancillary activities within the ss $70 \mathrm{~A}$ and $10 \mathrm{E}$ exclusions for primary activities that generate greenhouse gases and would, without the Amendment Act provisions, require consideration of climate change in air discharge consent applications.

\section{Identifying Potential Effects}

For the first step, actual and potential effects (adverse and positive) are identified in various RMA processes, including in the development of policy statements and plans, ${ }^{123}$ and in a proponent's assessment of environmental effects. ${ }^{124}$ Diffuse emissions and/or avoided emissions should be identified in those processes, such as those in the examples described above. There is nothing in the Amendment Act to permit councils and applicants to evade transparency in identifying and declaring greenhouse gas outcomes.

Section 70A only removes the ability for regional councils to make rules relating to discharges of greenhouse gases. By focusing on regional councils and on discharges of emissions, Parliament intended to permit territorial authorities to regulate diffuse sources of emissions. Similarly, s 104E only removes the consideration of greenhouse emissions for discharges to air permits. Otherwise, councils must make rules for and consider any "actual or potential effects", as per ss 3(e) (the meaning of effect), 30(1)(b) (functions of regional councils), 31(1)(b) (functions of territorial authorities), 68(3) (regional rules) and, of course, 104(1)(a) (consideration of applications), amongst other references throughout the RMA.

In terms of how diffuse emissions might be connected to the activity for which consents are sought, there has been judicial consideration of "potential effect". It does not mean that "no risk should be acceptable". ${ }^{125}$ It also does not apply to matters (such as landscaping) that are: ${ }^{126}$

122 See "Cities and Climate Change Initiative" UN Habitat <www.unhabitat.org>; C40 Cities <www.c40.org>; and "Low-carbon City" ICLEI <www.iclei.org>.

123 Resource Management Act 1991, s 32.

124 Section 88(2)(b) and sch 4. On substantive adequacy of assessments of environmental effects, see Derek Nolan Environmental \& Resource Management Law (4th ed, LexisNexis, Wellington, 2011) at [18.29].

125 See Aquamarine Ltd v Southland Regional Council EnvC Christchurch C126/97, 15 December 1997 at $144-$ 146, affirmed in Francks v Canterbury Regional Council [2005] NZRMA 97 (HC) at 104. 
... totally ancillary to the activity [of constructing a petrol station] and incapable of contributing cumulatively to the effects of the activity ... [and] will not increase the intensity of the activity nor alter the character of the activity... [nor] increase the size of the site of the proposed activity.

Essentially, a "potential effect" does not include very minor effects. This is because the approach adopted by the courts relates to orthodox methods of risk assessment, as explained in the Court of Appeal in Dye v Auckland Regional Council: ${ }^{127}$

Potential effects, in contrast [to cumulative effects], are effects which may happen or they may not.

Their definition incorporates levels of probability of occurrence. A high probability of occurrence is

enough to qualify the potential effect as an effect, whereas a potential effect which has a low probability

of occurrence qualifies as an effect only if its occurrence would have a high potential impact.

To this end, those effects that are relevant issues for consideration are "all reasonably foreseeable effects", and what this means is best explained by use of an example. ${ }^{128}$ In Aquamarine Ltd v Southland Regional Council, it was decided that the effects were not limited to those resulting from the activities for which consent was sought, which were for the development of a pipeline and a moor, so that fresh water could be taken from the environment and put into a tanker. Rather, the effects included those from boats' passages and discharges. ${ }^{129}$ In reaching that decision, Judge Skelton illustrates the relevance of "reasonably foreseeable effects" by referring to scenarios in which proposed activities, such as supermarkets, will have consequential traffic effects that "are regularly and hitherto without question regarded as relevant considerations". ${ }^{130}$

Diffuse emissions such as those from increased traffic effects were within Parliament's contemplations during the passage of the Resource Management (Energy and Climate Change) Amendment Bill: ${ }^{131}$

The bill specifically provides that councils should still consider the effects on climate change of their other decisions. Those decisions are legion. When a supermarket wants to locate a long way from town, the council has the right to consider how many more vehicle kilometres will have to be travelled for

126 Shell New Zealand Ltd v Porirua City Council HC Wellington CIV-2003-485-1476, 21 December 2004 at [57]

127 Dye v Auckland Regional Council, above n 45, at [39]; and see Sea-Tow Ltd v Auckland Regional Council EnvC Auckland A066/2006, 30 May 2006 at [341]-[342].

128 Aquamarine Ltd v Southland Regional Council (1996) 2 ELRNZ 361 (EnvC) at 366.

129 Aquamarine Ltd v Southland Regional Council, above n 128. See also Beadle v Minister of Corrections EnvC Wellington A074/2002, 8 April 2002 at [70]-[91]; and Cayford v Waikato Regional Council EnvC Auckland A127/98, 23 October 1998 at 10.

130 Aquamarine Ltd v Southland Regional Council, above n 128, at 366.

131 (5 August 2003) 610 NZPD 7596 per Jeanette Fitzsimons. 
people to get to that supermarket if it is away from where people live and away from public transport routes.

It seems virtually certain that such scenarios were in mind when it was stated in the Explanatory Note that "[t]he ability to control land uses for climate change purposes remains unchanged". ${ }^{132}$ Since the emissions from traffic stimulated by a supermarket development would be dwarfed by those eventuating from a coal mine, it seems certain that Parliament's intention was that the emissions resulting from coal's eventual combustion would satisfy the majority's questions about "tangibility" and cumulative effects. ${ }^{133}$

\section{D "The Development as a Whole"}

What remains, however, is avoiding "back door" regulation of activities requiring air discharge consents. For this, we must seek some way of limiting what effects can be considered, to give effect to the purpose of the Amendment Act.

In Burton v Auckland City Council, when determining what effects were to be considered with one of a number of resource consents, Blanchard J said: ${ }^{134}$

It seems to me that, at least where the other resource consent applications are to be made to the same consent authority, the assessment of actual or potential effects, as prepared in accordance with the

Fourth Schedule, must take into account relevant cumulative effects of the development as a whole.

In that case, the concept of "the development as a whole" was directed at capturing all of the effects of a development that required multiple consents. A concept of this nature was alluded to by Elias CJ in West Coast ENT Inc v Buller Coal Ltd in describing "the overall mining proposal". ${ }^{135}$ This "development as a whole" concept was aimed at ensuring that the Act's "sustainable management" and "integrated management" objectives were not subverted by incremental effects of discrete activities which, on their own, may have only minor effects. ${ }^{136}$

The same concept can, I contend, be used to avoid "back door" considerations of discharges to air. If greenhouse emissions that would (except for ss $70 \mathrm{~A}$ and $104 \mathrm{E}$ ) be the subject of an air discharge consent are identified in the assessment of environmental effects, then it becomes apparent to the consent authority that those emissions are, by extension of the effects of s 104E, irrelevant considerations for assessing under s 104(1)(a) the effects of activities that are "ancillary"

132 Amendment Bill 2003 (explanatory note), above n 102, at 5.

133 West Coast ENT Inc v Buller Coal Ltd, above n 1, at [121]-[127].

134 Burton v Auckland City Council [1994] NZRMA 544 (HC) at 554 (emphasis added).

135 West Coast ENT Inc v Buller Coal Ltd, above n 1, at [8].

136 Sections 5(2), 30(1)(a) and 31(1)(a); Burton v Auckland City Council, above n 134, at 554; and Aquamarine Ltd v Southland Regional Council, above n 128, at 366-367. 
to a "development as a whole". There is some uncertainty with this approach insofar as determining a trigger for excluding consideration of greenhouse emissions, but this would be resolved on a caseby-case basis according to the facts, and precedent indicators would evolve through case law. Furthermore, this "development as a whole" approach could borrow from the established principle of "overlapping consents" relied on for bundling multiple consent applications. This was summarised by Woolford $\mathbf{J}$ in Newbury Holdings Ltd $v$ Auckland Council: ${ }^{137}$

This occurs where there is such an overlap of the consents that, for the sake of efficiency, it makes sense

to bundle the overlapping consents and then apply the most restrictive status to all of them.

The "sake of efficiency" includes where the consideration of one consent may affect the outcome of another. ${ }^{138}$ It will be apparent on the facts of a case whether, for example, the activity requiring a land use consent "overlaps" with another activity requiring an air discharge permit. It is obvious here, for example, that the ancillary activities were intrinsically related to the main coal mining activity.

Rather than a major expansion of the reach of ss $70 \mathrm{~A}$ and 104E, this alternative, "development as a whole" approach gives effect to the purpose of the Amendment Act as defined above. It involves only a relatively minor qualification on the s 104(1)(a) assessment, it is consistent with the approach to bundling "overlapping" consents, and it is also consistent with authorities relating to courts correcting drafting errors.

\section{CORRECTING DRAFTING ERRORS AND FILLING GAPS}

"Words cannot be given 'meanings' they are incapable of bearing." 139

The majority did not state which provision of the Amendment Act is relied on for their decision but, as already noted, the most likely candidate is s 104E. However, to rely on s 104E required more than interpretation and indeed more than "stretching" the meaning of the words. It required a conclusion that there was a drafting error which caused absurdity that the court fixed as a matter of necessity. The majority explained: ${ }^{140}$

[T]he most likely explanation for the form of the 2004 Amendment Act is that those responsible for its drafting assumed the climate change arguments could only be advanced in relation to rules and consents involving direct discharges. In other words, the drafters did not envision that those same arguments

137 Newbury Holdings Ltd v Auckland Council [2013] NZHC 1172 at [59]; and see Bayley v Manukau City Council [1999] 1 NZLR 568 at 576; Hamilton v Far North District Council [2015] NZEnvC 12 at [16][17]; and Fonterra Co-operative Group Ltd v Manawatu-Wanganui Regional Council [2013] NZEnvC 250 at [44].

138 Tairua Marine Ltd v Waikato Regional Council HC Auckland CIV 2005-485-1490, 29 June 2006 at [30].

139 Burrows and Carter, above n 61, at 202.

140 West Coast ENT Inc v Buller Coal Ltd, above n 1, at [168]. 
could be made in relation to rules and consents relating to activities which indirectly result in, or facilitate the discharge of greenhouse gases. For the reasons given, such an assumption would have been very reasonable.

It would have been helpful if the majority had attempted to describe how the provision might have been rewritten without the error, so I will attempt to do so.

In its original state, s 104E provides: ${ }^{141}$

When considering an application for a discharge permit or coastal permit to do something that would otherwise contravene section 15 or section $15 \mathrm{~B}$ relating to the discharge into air of greenhouse gases, a consent authority must not have regard to the effects of such a discharge on climate change.

On the majority's interpretation, s 104E would read something akin to: "When considering any resource consent application, a consent authority must not have regard to the effects of any discharge of greenhouse gases on climate change."

Similarly, as enacted, s 70A provides: ${ }^{142}$

[W] hen making a rule to control the discharge into air of greenhouse gases under its functions under section $30(1)(d)(i v)$ or $(f)$, a regional council must not have regard to the effects of such a discharge on climate change.

On the majority's interpretation, s 70A would read something akin to:

[W] hen making rules under its functions under s 30 or s 31, a consent authority must not have regard to the effects on climate change of any discharge of greenhouse gas emissions...

When rewritten like this, it is clear that the changes necessitated by the majority's reasoning were not minor but actually significant. The question arises whether that was justifiable. In Inco Europe Ltd v First Choice Distribution, the House of Lords accepted that courts can fix "obvious drafting errors", subject to stringent conditions: ${ }^{143}$

This power is confined to plain cases of drafting mistakes. ... [T] he courts exercise considerable caution before adding or omitting or substituting words. Before interpreting a statute in this way the court must be abundantly sure of three matters: (1) the intended purpose of the statute or provision in question; (2) that by inadvertence the draftsmen or Parliament failed to give effect to that purpose in the provision in question; and (3) the substance of the provision Parliament would have made, although not necessarily the precise words Parliament would have used, had the error in the Bill been noticed. The third of these

141 Emphasis added.

142 Emphasis added.

143 Inco Europe Ltd v First Choice Distribution [2000] 2 All ER 109 (HL) at 115. See also Jones v Wrotham Park Settled Estates and anor [1979] 1 All ER 286 (HL) at 289 per Lord Diplock. 
conditions is of crucial importance. Otherwise any attempt to determine the meaning of the enactment would cross the boundary between construction and legislation. ...

Sometimes, even when these conditions are met, the court may find itself inhibited from interpreting the statutory provisions in accordance with what it is satisfied was the underlying intention of Parliament. The alteration in language may be too far-reaching. In Western Bank Ltd v Schindler [1977] Ch. 1, 18, Lord Scarman observed that the insertion must not be too big, or too much at variance with the language used by the legislature.

It is worth reiterating Lord Nicholls' very strong language to specify the limitations -"plain cases of drafting mistakes", "considerable caution", "must be abundantly sure", "crucial importance". ${ }^{144}$ Cooke $\mathrm{P}$ also espoused caution with respect to filling supposed gaps in legislation: ${ }^{145}$

Courts must try to make the Act work while taking care not themselves to usurp the policy-making function, which rightly belongs to Parliament. The Courts can in a sense fill gaps in an Act but only in order to make the Act work as Parliament must have intended.

When gaps have been filled in prior judgments, the alterations read in are minor in comparison to those effected in West Coast ENT Inc v Buller Coal Ltd. For example, in $R v$ Wall, a qualification was implied into a provision in the Misuse of Drugs Amendment Act 1978. The provision prevented the admission of evidence from intercepted communications relating to offences other than drug dealing offences. ${ }^{146}$ The qualification read in was that communications that evidenced both drug dealing and other offences was admissible, otherwise a person who admitted to drug dealing and murder would be better off than someone who admitted only to drug dealing, because the evidence of the other offence could not be admitted. This met the test that "[v]ery strong reasons are essential before a Court is justified in departing from the apparent plain meaning". ${ }^{147}$

A similarly minor qualification was also implied into a provision in Re Bank of New Zealand. Under the Companies Act 1993, companies are required to add the word "Limited" to their name when they re-register. However, a qualification was read into that requirement, which was that "Limited" did not need to be added to the company name "Bank of New Zealand" because the bank's name was specified in the statute that established it. Reading in that qualification, the

144 Inco Europe v First Choice Distribution, above n 143, at 115, citing with approval Jones v Wrotham Park, above $\mathrm{n} 141$.

145 Northland Milk Vendors Association Inc v Northern Milk Ltd [1988] 1 NZLR 530 (HC) at 538.

$146 R v$ Wall [1983] NZLR 238 (CA) at 240.

147 At 240 per Cooke J. 
provision still "function[ed] within a wider whole"148 and did not affect any "wider and contrary policy matters". ${ }^{149}$

Referring back to the three tests for fixing drafting errors in Inco Europe, these conditions are predicated on a purposive interpretation, as is Cooke P's observation in Northland Milk Vendors Association Inc v Northern Milk Ltd. The purpose of the Amendment Act was, according to my analysis, only to carve out consideration of greenhouse emissions related to projects that require an air discharge permit. Even without that interpretation, the rephrased ss 104E and 70A above shows that the majority's interpretation was, as Elias CJ said in dissent, a "substantial gloss of the terms of the statute to exclude such considerations". ${ }^{150}$ It was beyond the gloss envisaged by the House of Lords in Inco Europe. It was also inconsistent with the additional concern of the High Court in Re Bank of New Zealand for "wider and contrary policy matters", insofar as the wholesale removal of climate change considerations from the RMA curtails New Zealand's efforts to scale up mitigation efforts without double regulation via the CCRA and RMA. ${ }^{151}$ By comparison, the gloss that I have proposed is a minor qualification that, I contend, meets the stringent tests in Inco Europe, is consistent with scale of corrections in $R v$ Wall and Re Bank of New Zealand, and is consistent with Parliament's intentions.

\section{INTERNATIONAL LAW CONTEXT}

The RMA predates developments in international climate change law and the Explanatory Note to the Bill for the Amendment Act does not purport to have a specific role in meeting any of New Zealand's international obligations, although it does state that it is "consistent with the direction of the Kyoto Protocol". ${ }^{152}$ Regardless of these facts, there is nothing preventing the court from referring to international law when interpreting the RMA. Indeed, before the 2004 Amendment Act, the Environment Court had deemed international climate change instruments to be relevant considerations. ${ }^{153}$

The principle for employing international instruments in statutory interpretation was enunciated by Keith J in New Zealand Air Line Pilots' Association v Attorney-General: ${ }^{154}$

148 Re Bank of New Zealand [1997] 2 NZLR 239 (HC) at 250.

149 At 251

150 West Coast ENT Inc v Buller Coal Ltd, above n 1, at [24].

151 Re Bank of New Zealand, above n 148, at 251.

152 Amendment Bill 2003 (explanatory note), above n 102, at 8.

153 Environmental Defence Society Inc v Auckland Regional Council [2002] NZRMA 492 (EnvC) at [28].

154 New Zealand Air Line Pilots' Association Inc v Attorney-General [1997] 3 NZLR 269 (CA) at 289 per Keith J. See also Ye v Minister of Immigration [2009] NZSC 76, [2010] 1 NZLR 104 (SC) at [21], [24] and [32]; Tavita v Minister of Immigration [1994] 2 NZLR 257 (CA) at [265]-[266]; Ashby v Minister of Immigration 
We begin with the presumption of statutory interpretation that so far as its wording allows legislation should be read in a way which is consistent with New Zealand's international obligations. That presumption may apply whether or not the legislation was enacted with the purpose of implementing the relevant text. ... The application of the presumption depends on both the international text and the related national statute.

In the Environment Court, a request to consider an interpretation of the Amendment Act in light of the international setting was refused because of the caveat in Keith J's statement. Newhook LJ stated: 155

[Although] this principle of statutory interpretation will arise where the wording of the legislation allows, or there is ambiguity, or where the Court for one reason or another has a choice of interpretation

... I am not persuaded that there is any discretion concerning interpretation, or any ambiguity or choice.

In the High Court, Whata $\mathrm{J}$ did not respond to counsel's concern that fettering local government's consideration of greenhouse emissions by implication was contrary to New Zealand's commitment to international convention. ${ }^{156}$ In the Supreme Court, Elias CJ noted that those emissions that are not subject to the RMA under her interpretation of the Amendment Act would be, "[f]or the purposes of limiting emissions to fulfil New Zealand's international obligations ... managed by the Emissions Trading Scheme". ${ }^{157}$ The majority described the international context, such as the UNFCCC and the Kyoto Protocol, and noted that: ${ }^{158}$

The Climate Change Response Act established the machinery which was necessary to ensure that New

Zealand was able to comply directly with its obligations under the UNFCCC and the Kyoto Protocol.

The majority also noted that New Zealand has declined to give a further commitment beyond the expiry of the Kyoto Protocol. Beyond those observations, the majority made no statement on whether international law could colour the interpretation of the Amendment Act, so one is forced to presume that the majority reasoned that the language of the Amendment Act could not bear an interpretation other than that which they concluded upon. It would have been desirable for the majority to have been explicit about that.

The analysis above shows that there are at least three potential interpretations of the purpose of the amended RMA as it affects the interpretation of the provisions at play, ss 104(1)(a) and 104E:

[1981] 1 NZLR 222 (CA) at 226; and Puli'uvea v Removal Review Authority [1996] 3 NZLR 538 (CA) at $541-542$.

155 Buller Coal Ltd $v$ West Coast Ent, above n 2, at [38]

156 Royal Forest and Bird v Buller Coal, above n 4, at [7](g).

157 West Coast ENT Inc v Buller Coal Ltd, above n 1, at [44], and see [66].

158 At [101] (emphasis added). 
the majority's, Elias CJ's and mine. As the caveat in New Zealand Air Line Pilots' Association v Attorney-General is that an international lens is not used only when the text cannot bear it, the range of possible interpretations demands that we fall back on the presumption of consistency. In fact, the plain text cannot directly bear the majority's interpretation either, so an international lens cannot be avoided on that.

There are principles contained in the relevant international instruments that could guide the interpretation of the amended RMA. The UNFCCC, for example, sets out principles such as: "The Parties should protect the climate system for the benefit of present and future generations of humankind"; and "The Parties should take precautionary measures to anticipate, prevent or minimize the causes of climate change". ${ }^{159}$ The Kyoto Protocol sets out obligations such as: "Each Party ... shall ... implement and/or elaborate policies and measures in accordance with its national circumstances". ${ }^{160}$

The Ministry for the Environment has forecast that New Zealand will meet and, indeed, slightly exceed its specified 2008-2012 mitigation target under the Kyoto Protocol. ${ }^{161}$ One might argue that this negatives any requirement to interpret the RMA amendments in any way that enables further mitigation of climate change, and it may do. There are, however, multiple reasons why the international context must persist as an tool for interpreting how the Amendment Act affected the RMA.

First, the UNFCCC exists as international law in perpetuity, and so does the Kyoto Protocol, at least until it is replaced by an updated protocol. Secondly, New Zealand remains a party to those instruments and the object of protecting the climate system by minimising the causes of climate change. Thirdly, New Zealand is an active participant in ongoing negotiations to secure a binding agreement that succeeds the Kyoto Protocol and it has adopted voluntary emissions reduction targets, and both of these facts signal an ongoing intention to cooperate in and be bound by international efforts to mitigate climate change. ${ }^{162}$ Fourthly, the Conference of Parties to the UNFCCC, which includes New Zealand, has agreed in the non-binding Copenhagen Accord "that the increase in global temperature should be below 2 degrees Celsius", ${ }^{163}$ which will require

159 UNFCCC, above $\mathrm{n} 98$, arts 3(1) and 3(3).

160 Kyoto Protocol, above n 98, art 2(1)(a).

161 Ministry for the Environment "New Zealand's net position under the Kyoto Protocol" (11 April 2014) <www.mfe.govt.nz>.

162 See Ministry of Foreign Affairs and Trade "Environment: Shaping a global response to Climate Change" (2 July 2014) <www.mfat.govt.nz>; and New Zealand Government "Submission to the Ad Hoc Working Group on the Durban Platform for Enhanced Action: Work Stream 1" (March 2014) at United Nations Framework Convention on Climate Change "Submissions from Parties to the ADP in 2014" <www.unfccc.int>.

163 Copenhagen Accord, above n 18, art 1. 
massive cuts in global emissions eventually reaching zero emissions. ${ }^{164}$ Fifthly, in the same way that achieving some goals of international human rights instruments does not bring their relevance to an end, meeting initial, short-term climate change targets (as the Ministry has forecast with respect to the Kyoto) does not satisfy the longer-term objective. Sixthly, because another legislative instrument specifically gives effect to the relevant international instruments, that does not discount the relevance of those international instruments to other domestic legislation. If that were so, then international human rights norms, for example, would apply to a very limited range of enactments.

In that context, it is proper "to assume that our Parliament did not intend to legislate inconsistently with New Zealand's international obligations". ${ }^{165}$ Here, that would mean preferring an interpretation that does not prohibit local regulation of sources of greenhouse gas emissions which are not directly affected by the Amendment Act.

\section{CONCLUSION}

The majority's conclusion was that "it is not open to territorial authorities and regional councils to regulate activities by reference to the effect on climate change of discharges of greenhouse gas emissions". ${ }^{166}$ This effectively removes all consideration of greenhouse gases, whether those gases are emitted directly, indirectly, diffusely, or in fact reduced. Could it have really been Parliament's true intention to remove from the internal workings of the New Zealand's principal piece of environmental legislation virtually all opportunities, both negative and positive, to consider the one environmental issue that adversely affects all others?

The majority's conclusion was not inevitable. The analysis here leads to the alternative conclusion that the effect of the 2004 Amendment Act was two-fold. First, it explicitly removed the consideration of greenhouse gas emissions with respect to air discharge permits. Secondly, it implicitly removed the consideration of greenhouse gases for activities that are ancillary to a "development as a whole" which requires an air discharge permit.

How would this conclusion have affected the outcome of the West Coast ENT Inc v Buller Coal Ltd decision? Since the purpose of the development as a whole was to mine (but not combust) the coal, the coal's ultimate end use should have been deemed a potential adverse effect that was, therefore, to be considered during the application and decision making processes. The land use activities were indeed ancillary to the main development, but since that development did not include an air discharge permit, then the excisions of ss $70 \mathrm{~A}$ and $104 \mathrm{E}$ were irrelevant.

164 Macey, above n 16, at 49.

165 Burrows and Carter, above n 61, at 26.

166 West Coast ENT Inc v Buller Coal Ltd, above n 1, at [175]. 
This outcome would have resulted in double regulation: via the RMA and via the CCRA. ${ }^{167}$ However, if that was considered to be an undesirable outcome, then either the RMA or the CCRA could have been amended in a manner that suited Parliament. It was not up to the Supreme Court to decide which of those policy solutions was preferable.

167 Climate Change Response Act 2002, sch 3, pt 1, subpt 1. 
